\title{
ウォーターインソール使用後の足部血流の変化 \\ The Increase in Skin Blood Flow by Wearing Water Insole
}

\author{
○入澤 寛 ${ }^{1}$ ，美津島 隆 ${ }^{1}$ ，山内 克哉 ${ }^{1}$ ，森田 信義 ${ }^{2}$ \\ 1. 浜松医科大学附属病院リハビリテーション科, 2. 静岡大学工学部 \\ OHiroshi IRISAWA ${ }^{1}$, Takashi MIZUSHIMA ${ }^{1}$, Katsuya YAMAUCHI ${ }^{1}$, and Nobuyoshi MORITA ${ }^{2}$ \\ 1. Hamamatsu University School of medicine, 2. Shizuoka University
}

\begin{abstract}
1. 目的
ウォーターインソールは静岡大学工学部で開発されたインソー ル(靴の中敷き)であり, インソール内に水とその流れをコントロー ルする堰とオリフィスで構成されている. 2005 年の本学会で報告 されたように, 歩行時の衝撃吸収に対して 有効であることが証明 されている 1). 今回我々はウォーターインソールによる足部血流 改善効果を検証し、今後の臨床応用の可能性について検討した.
\end{abstract}

\section{2. 方法}

健常男女 8 名(男性 7 名、女性 1 名 21 歳から 38 歳 平均 27.3 歳)で測定した. 血流測定はドプラ血流計 (OMEGAWAVE 社製) にて行った. ドプラ血流計は測定部位の動きによるノイズ出現お よびセンサーのずれが多く実際の歩行時の血流変化を測定する ことは困難であった，そこで, 歩行の代わりに足踏み運動での血. 流変化を測定することとした．血流測定は動作による影響の少な い第一趾尖で行うこととした . ウォーターインソールを着用した状 態, 着用しない状態で安静を 4 分, 足踏み運動を 2 分間実施し, その後の足部血流の変化を 4 分間ドプラ血流計にて測定し血流 を比較した。

\section{3. 結果}

ウォーターインソール着用群は, 非着用群と比較して足部血流 の值が足踏み運動後 90 秒間および 121 秒から 150 秒の間で有 意に高值を示した (図1). また, 足踏み運動前の血流の平均值と の比較では, 足踏み運動後 90 秒間, および 121 秒から 150 秒後, 181 秒から 240 秒後で有意に血流が増加していた(図2).

\section{4. 考察}

ウォーターインソールは堰とオリフィスで流れをコントロールする ことにより, 歩行に伴って衝撃吸収が必要な場所に水を流し，か つ衝撃吸収が必要な部分に水をためることができる構造になって いる. また、立脚相に水が踵部から足尖部に移動することによっ て, 足底マッサージ効果が得られる. 被験者からはこれまでもマッ サージ効果があるとの感想が得られていた。

これまでの報告より 2), 本実験で得られた血流増加効果はこの 足底マッサージ効果によるものと考えられる.

本インソールの臨床応用として

・足部潰瘍のリスクがある糖尿病患者

糖尿病における足部潰瘍の発生率は高く, そのリスクファクタ 一として, 微小循環障害による皮膚血流の悪化, 靴の不適合 による過度な圧負荷が挙げられる 3，4）. 本インソールの使用 によって潰瘍発生リスクを減少させる可能性がある.

・冷え性を自覚する患者

冷え性を自覚する患者では足部皮膚血流が低下することが 指摘されている5)，本インソールの血流改善効果によって自覚 症状を改善できる可能性がある。

\section{5. 結語}

ウォーターインソール着用による皮膚血流変化について報告し た. ウォーターインソール着用により, 足部皮膚血流は増加した.
今後臨床応用に向け, 評価を行っていく予定である.

\section{6. 参考文献}

1）森田信義, 他, 衝撃吸収に優れたウォーターインソールの 開発, 福祉工学シンポジウム 2005, 2005.

2) Goats GC , Massage--the scientific basis of an ancient art: Br J Sports Med. 1994 Sep; 28(3):149-156.

3) Haris M. Rathur, Andrew J. M. Boulton, The Diabetic Foot, Clinics in Dermatology 2007; 25: 105-120.

4）渥美義仁, 糖尿病の足病変とケア,

MEDICAL REHABILITATION 2004;47:52-57.

5) 後山尚久, 冷え性の病態の臨床的解析と対応, 医学のあ ゆみ 2005;215(11):925-929.

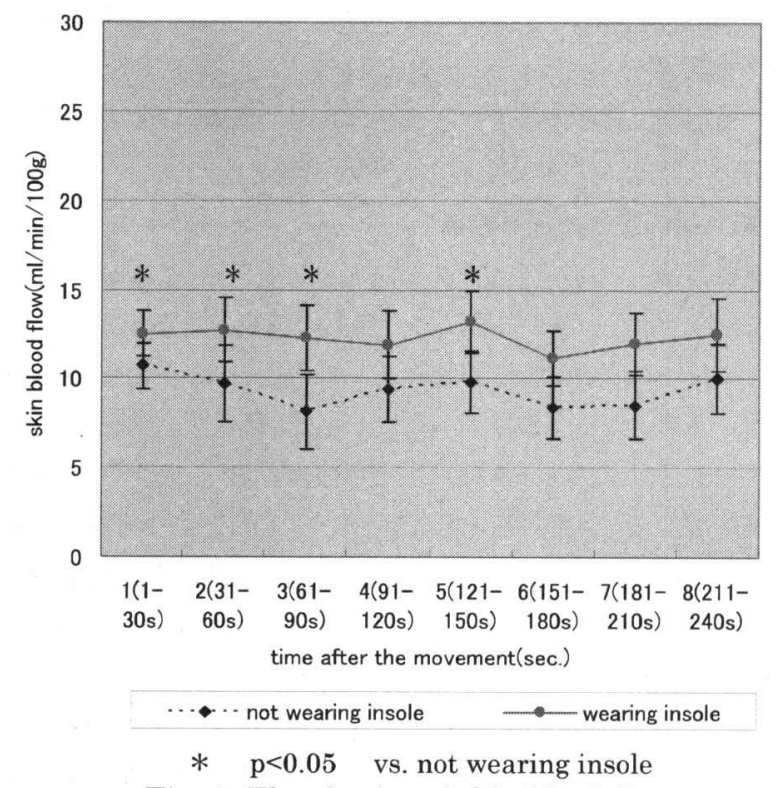

Fig. 1 The change of skin blood flow

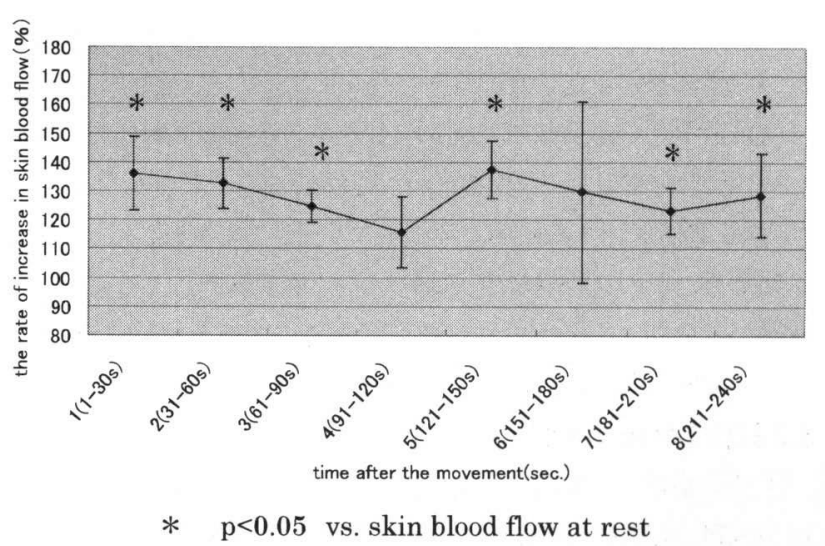

Fig. 2 The rate of increase in skin blood flow 